\title{
Effect of Alpha-Tocopherol on Biochemical Parameters in Commercial Broilers during Heat Stress
}

\author{
Amir Amin Sheikh ${ }^{1}$, Aditya Mishra ${ }^{1}$, Kailash Kumar ${ }^{1}$, Pragati Patel ${ }^{1}$, \\ A.K. Jain ${ }^{1}$, Showkeen M. Bashir ${ }^{2 *}$ and Aarif Ali $^{2}$ \\ ${ }^{1}$ Department of Veterinary Physiology and Biochemistry, College of Veterinary Science and \\ Animal Husbandry, Nanaji Deshmukh Veterinary Sciences University, Jabalpur-482 001, \\ Madhya Pradesh, India \\ ${ }^{2}$ Division of Veterinary Biochemistry, Sher-e-Kashmir University of Agricultural Science and \\ Technology, Shuhama, Alusteng, Srinagar, (J\&K), India \\ *Corresponding author
}

A B S T R A C T

\begin{tabular}{|c|}
\hline Keywords \\
\hline $\begin{array}{l}\text { Alpha-tocopherol, } \\
\text { Commercial broilers, } \\
\text { Plasma ascorbic acid, } \\
\text { Plasma albumin, } \\
\text { Plasma glucose, } \\
\text { Breast muscle pH, } \\
\text { Thio-barbituric acid. }\end{array}$ \\
\hline Article Info \\
\hline $\begin{array}{l}\text { Accepted: } \\
07 \text { September } 2017 \\
\text { Available Online: } \\
10 \text { October } 2017\end{array}$ \\
\hline
\end{tabular}

Thio-barbituric acid.

Article Info

Accepted:

Available Online

10 October 2017
Poultry production suffers huge losses due to heat stress, which is caused by high temperatures in many areas during the summer. Thus, the environment in which the broilers are reared is considered a key factor for success from the economic point of view. Therefore, maximum production requires the elimination of the deleterious impacts of environmental stressors. The objective of this study was to quantify plasma ascorbic acid, plasma albumin, plasma glucose, breast muscle $\mathrm{pH}$, thio-barbituric acid value during heat stress in commercial broilers. A total number of 96 birds were randomly divided into 4 groups and each group consist of 12 birds in two replicates. Work was done in two conditions, heat and comfort. Heat stressed groups were maintained at $37 \pm 5.0^{\circ} \mathrm{C}$ whereas Comfort groups were maintained at $26 \pm 1.0^{\circ} \mathrm{C}$. G1 was taken as control whereas G2, G3 and G4 was supplemented with $100 \mathrm{mg}, 200 \mathrm{mg}$ and $300 \mathrm{mg}$ of vitamin E respectively. G4 group supplemented with $300 \mathrm{mg}$ of alpha-tocopherol showed better results as compared to other supplemented and non-supplemented groups. This shows Vitamin E has potential antioxidant effect able to modulate physiological adjustments to mitigate the undesirable effects of exposure of broilers to high temperatures.

\section{Introduction}

Among various environmental conditions, high ambient temperature beyond the range of the thermoneutral zone in poultry has been known as one of the most fatal stressors, which adversely affects feed intake, growth rate, immunity and mortality (Niu et al., 2009). Therefore, preventing and alleviating the heat stress (HS) against summer high ambient temperature is becoming increasingly important in the poultry industry.
When chickens are exposed to high temperature, they try to reduce their body temperature within a narrow range through self-thermal regulation to maintain body homeostasis. In particular, the exposure of poultry to summer HS is stressful enough to induce their metabolic rate and physiological responses to cope with the thermal environment (Puthpongsiriporn et al., 2001). Therefore, vitamin E supplementation appears 
to play a major role in the improvement of poultry production performance during heat stress.

Sahin et al., (2001) reported supplementation of vitamin $\mathrm{E}$ alone has been reported to reduce the negative effects of heat stress in broilers. One of the most important properties of vitamin $\mathrm{E}$ is its antioxidant function. When animals fed diets rich in unsaturated fatty acids which are susceptible to peroxidation, the vitamin $\mathrm{E}$ deficiency is augmented (McDowell, 1989).

\section{Materials and Methods}

The experiment was conducted at college of veterinary science and animal husbandry, N.D.V.S.U., Jabalpur, Madhya Pradesh.

\section{Birds and management}

Total ninety six (96) day old chicks of commercial broiler birds were procured from private hatcheries of Jabalpur. The birds were maintained in the battery cage system in a well-ventilated room in the poultry experimental unit at college with prior permission from Institutional Animal Ethics Committee. Artificial heat was provided to chicks during early period (brooding period) of growth using thermostatically controlled electric brooders. The battery brooders were cleaned, washed and disinfected by blow lamping and complete house was fumigated using formaldehyde and potassium permanganate four days prior to start of the experiment. Feeders and waterers were carefully cleaned with detergent. Duration of experiment was six months. The feed was offered ad-libitum in linear chicks. Aluminum plates of appropriate size and small tin boxes were used in each cage to offer water during early weeks. Due care was taken so that the chicks reach the feeder and waterer in the first week of age. Later on, large size feeders and waterers were attached to each cage in opposite direction. All-mash system of feeding was practiced during the experiment. Fresh and clean drinking water was made available to birds all the time. Thus, during entire period of study uniform conditions of housing, brooding, feeding and watering was maintained for all the groups of the experiment. Broiler birds randomly divided into eight groups. Four groups of birds were maintained in summer conditions (May to June) maintained in heat stress $\left(37 \pm 5.0^{\circ} \mathrm{C}\right)$ ambience, whereas other four groups of birds was maintained at $26 \pm 1.0^{\circ} \mathrm{C}$ (comfort temperature) using an air conditioner. Broilers were kept in closed ventilated system for 45 days during the experimental period. Temperature and humidity of the experimental poultry unit was recorded using a digital thermo-hygrometer.

\section{Methods}

Diets were formulated as per NRC (1994) specifications presented in table 1. For analysis of biochemical parameters, blood was collected from individual birds on specified day of experiment i.e. on $15^{\text {th }}, 30^{\text {th }}$ and $45^{\text {st }}$ day. The blood samples were collected by cleaning the area by plucking the feather and wiping the area by ethanol swab. A 22 gauge needle was used for collection of blood. The blood samples were collected in heparinized polypropylene tubes (20 IU heparin/ml of blood) were kept in the ice bucket and carried back to the laboratory immediately. In the laboratory, all the blood samples were centrifuged at $3000 \mathrm{rpm}$ for 30 min and plasma was separated. Plasma obtained was kept in the labeled storage vials of $2 \mathrm{ml}$ capacity and stored at $-20^{\circ} \mathrm{C}$ till analysis for biochemical parameters. The plasma ascorbic acid was estimated using DCIP method described by (Omaye et al., 1979). Plasma glucose concentration was estimated by Trinder's method (Pileggi and Szuskeiweiz, 1974) using diagnostic kits 
procured from Erba Diagnostics, Mannheim Gmbh, Germany. The concentration was expressed in $\mathrm{mg} / \mathrm{dl}$ of blood glucose. Plasma albumin concentration was estimated as per method described by Doumas et al., (1972) using diagnostic kits procured from Erba Diagnostics, Mannheim Gmbh, Germany. The concentration was expressed in $\mathrm{g} / \mathrm{dl}$ of albumin. Automatic biochemistry analyzer was used for the determination of plasma ascorbic acid and albumin concentration.

The $\mathrm{pH}$ was determined using a modification of the iodoacetate method described by Petracci et al., (2004). Lipid peroxidation was determined by a micro method for TBAreactive substances (TBARS). Approximately $100 \mathrm{mg}$ of liver was incubated in $0.5 \mathrm{~mL} 50 \%$ trichloroacetic acid containing $1.3 \%(\mathrm{wt} / \mathrm{vol}$ ) thiobarbituric acid (dissolved at $60^{\circ} \mathrm{C}$ ) and heated at $60^{\circ} \mathrm{C}$ for $1 \mathrm{~h}$, followed by determination of absorbance of supernatant at $532 \mathrm{~nm}$. Tetraethoxypropane, which spontaneously decomposes in an aqueous environment to form malondialdehyde (MDA), was used as a standard and absorbance was expressed as MDA equivalents. MDA equivalents were calculated after subtraction of blank (water), correction for turbidity measured at $650 \mathrm{~nm}$ and dilution of the TBA reagent from water contained in the meat. The recorded data was statistically analyzed using Completely Randomized Design (Snedecor and Cochran, 1994). Various conditions and treatment groups were compared by using Duncan Multiple Range test (DMRT).

\section{Results and Discussion}

The data recorded and analyzed for plasma ascorbic acid is represented in (Table 2). The overall mean concentration of plasma ascorbic acid (AA) showed non-significant difference between comfort and heat stressed birds in alpha-tocopherol supplemented groups. In comfort condition, maximum
$(5.27 \pm 0.18 \mathrm{mg} / \mathrm{dl})$ and minimum $(4.36 \pm 0.15$ $\mathrm{mg} / \mathrm{dl})$ concentration of plasma AA was observed in G4 and control group respectively which differ significantly $(\mathrm{p}<0.01)$. However, in $\mathrm{G} 3$ and $\mathrm{G} 1$ non-significant difference was observed. In heat stressed condition, maximum $(5.51 \pm 0.17 \mathrm{mg} / \mathrm{dl})$ and minimum $(5.47 \pm 0.14 \mathrm{mg} / \mathrm{dl})$ concentration of plasma AA was observed in G4 and control group respectively which differ non-significantly $(\mathrm{p}<0.05)$. Further, non- significant difference was observed in G2 and G3 and similar trend was observed in $\mathrm{G} 1$ and $\mathrm{G} 2$ group.

The data recorded and analyzed for plasma glucose is represented in (Table 3). The overall mean concentration of glucose showed non-significant difference between comfort and heat stressed birds in alpha-tocopherol supplemented groups. In comfort condition, G3 and G4 group differ significantly $(p<0.01)$ from $\mathrm{G} 1$ but non-significant difference was observed between G2, G3 and G4 group.

Also, G1 and G2 group differed nonsignificantly. In heat stressed condition nonsignificant difference was observed between G3 and G4. Similar trend was also observed between G5 and G6. Group G1 control group differ significantly $(\mathrm{p}<0.01)$ from all alphatocopherol treated groups of heat stressed condition showing minimum concentration $(216.19 \pm 6.79 \mathrm{mg} / \mathrm{dl})$ of glucose. On supplementation of $100 \mathrm{mg}, 200 \mathrm{mg}$ and 300 $\mathrm{mg}$ vitamin $\mathrm{E}$ in feed, it was found that the overall mean concentration of glucose showed non-significant difference between comfort and heat stressed birds in all the groups. In comfort condition, present means of plasma glucose at $45^{\text {th }}$ day, on supplementation of vitamin E (302.05 $\pm 03.77 \mathrm{mg} / \mathrm{dl})$. The present findings were in accordance to findings reported by Navid et al., (2010). Whereas, Sahin et al., (2001) reported that there was lower glucose concentration in broilers supplemented with vitamin $\mathrm{E}$ which were in disagreement to present findings. 
Increase in glucose levels at higher ambient temperature would be due to the endocrine mechanism of stress regulation. The hypoglycaemia resulted due to stress conditions led to stimulation of hypothalamus and release of ACTH from anterior pituitary which caused the increase of adrenal cortical steroid secretions. Continuous stimulation to adrenal cortex led chronically high levels of corticosteroid hormones. This hormone is responsible for the formation of glucose from body's reserves of carbohydrates, lipids and proteins. Glucocorticoids also have primary effects on metabolism, stimulating glucogenesis leading to increased blood glucose levels (Sturkie, 1986 and Khatibjoo et al., 2014). These results could be explained by that, birds under environmental stress underwent an increase in plasma glucose which may be correlated with increase in corticosterone hormone secretion to supply the body with energy (Siegel, 1995).

The data recorded and analyzed for plasma albumin is represented in (Table 4). The overall mean concentration of albumin showed non-significant difference between comfort and heat stressed birds in alphatocopherol supplemented groups. In comfort condition, G3 and G4 group differ significantly $(p<0.01)$ from $\mathrm{G} 1$, but nonsignificant difference was observed between G2, G3 and G4 groups. Also, G1 and G2 group differ non-significantly. In heat stressed condition significant $(\mathrm{p}<0.01)$ difference was observed between the G1, G3 and G4 groups. Similar trend was also observed between G2 and G4.

Table.1 Formula and chemical composition of broiler ration

\begin{tabular}{|l|c|c|}
\hline Ingredients & Starter \% & Finisher \% \\
\hline Maize & 58.805 & 59.50 \\
\hline Soybean & 28 & 26 \\
\hline Sunflower meal & 5 & 2.5 \\
\hline Fish meal & 5 & 3 \\
\hline Limestone & 1.0 & 0.8 \\
\hline Di-calcium phosphate & 1.5 & 1.1 \\
\hline Salt & 0.2 & 0.2 \\
\hline DL- Methionine & 0.06 & 0.04 \\
\hline Trace mineral Premix & 0.1 & 0.1 \\
\hline Vitamin premix* & 0.15 & 0.15 \\
\hline Vitamin B complex** & 0.015 & 0.015 \\
\hline Choline chloride & 0.05 & 0.05 \\
\hline Toxin binder & 0.05 & 0.05 \\
\hline Protexim & 0.02 & - \\
\hline Coccidiostat & 0.05 & 0.05 \\
\hline De-oiled rise bran & - & 1.42 \\
\hline Rape seed meal & - & 5 \\
\hline Lysine & - & 0.02 \\
\hline Total & 100 & 100 \\
\hline Nutrient Composition & \multicolumn{2}{|c|}{} \\
\hline Crude protein $(\%)$ & 21.66 & 18.98 \\
\hline Metabolizable energy (Kcal. ME/Kg)*** & 2843 & 2850 \\
\hline Calcium (\%) & 1.17 & 1.17 \\
\hline Available phosphorus (\%) & 0.496 & 0.5 \\
\hline Lysine (\%) & 1.24 & 1.22 \\
\hline
\end{tabular}

*Trace mineral Premix: Mg-300, mn-55, I-0.4, fe-56, Zn-30 and Cu-4kg-1

** Vitamin premix: Vitamin A-8250 IU, Vitamin $\mathrm{D}_{3}-1200 \mathrm{IU}$, Vitamin K-1mg, Vitamin B1-2mg, Vitamin $\mathrm{B}_{2}-4 \mathrm{mg}$, Vitamin $\mathrm{B}_{12}-10 \mathrm{mg}$, Percent of values specified by NRC, 1994, *** Calculated. 
Table.2 Mean plasma ascorbic acid concentration $(\mathrm{mg} / \mathrm{dl})$ of broilers at different intervals

\begin{tabular}{|c|c|c|c|c|c|}
\hline Period & Condition & G1 & G2 & G3 & G4 \\
\hline \multirow{2}{*}{$15^{\text {th }}$ day } & Comfort & $\begin{array}{c}4.89^{\mathrm{B}} \pm 0.29 \\
(12)\end{array}$ & $\begin{array}{c}4.53^{\mathrm{B}} \pm 0.24 \\
\text { (12) }\end{array}$ & $\begin{array}{c}4.53^{\mathrm{B}} \pm 0.24 \\
\text { (12) }\end{array}$ & $\begin{array}{c}5.93^{\mathrm{A}} \pm 0.31 \\
(12)\end{array}$ \\
\hline & Heat & $\begin{array}{c}5.35^{\mathrm{B}} \pm 0.21 \\
\text { (12) }\end{array}$ & $\begin{array}{c}4.34^{\mathrm{B}} \pm 0.16 \\
(12)\end{array}$ & $\begin{array}{c}4.34^{\mathrm{B}} \pm 0.16 \\
(12)\end{array}$ & $\begin{array}{c}5.51^{\mathrm{A}} \pm 0.32 \\
(12)\end{array}$ \\
\hline \multirow{2}{*}{$30^{\text {th }}$ day } & Comfort & $\begin{array}{c}4.09^{\mathrm{B}} \pm 0.19 \\
(12)\end{array}$ & $\begin{array}{c}4.10^{B} \pm 0.21 \\
(12)\end{array}$ & $\begin{array}{c}4.10^{\mathrm{B}} \pm 0.21 \\
(12)\end{array}$ & $\begin{array}{c}5.16^{\mathrm{A}} \pm 0.28 \\
(12)\end{array}$ \\
\hline & Heat & $\begin{array}{c}5.87 \pm 0.26 \\
(12)\end{array}$ & $\begin{array}{c}4.81 \pm 0.26 \\
(12)\end{array}$ & $\begin{array}{c}4.81 \pm 0.26 \\
(12)\end{array}$ & $\begin{array}{c}5.72 \pm 30 \\
(12)\end{array}$ \\
\hline \multirow{2}{*}{$45^{\text {st }}$ day } & Comfort & $\begin{array}{c}4.09^{\mathrm{B}} \pm 0.20 \\
(12)\end{array}$ & $\begin{array}{c}4.62^{\mathrm{B}} \pm 0.17 \\
\text { (12) }\end{array}$ & $\begin{array}{c}4.62^{\mathrm{B}} \pm 0.17 \\
(12)\end{array}$ & $\begin{array}{c}4.73^{\mathrm{A}} \pm 0.26 \\
\text { (12) }\end{array}$ \\
\hline & Heat & $\begin{array}{c}5.19^{\mathrm{B}} \pm 0.23 \\
(12)\end{array}$ & $\begin{array}{c}5.22^{\mathrm{B}} \pm 0.26 \\
(12)\end{array}$ & $\begin{array}{c}5.22^{\mathrm{B}} \pm 0.27 \\
(12)\end{array}$ & $\begin{array}{c}5.30^{B} \pm 0.26 \\
(12)\end{array}$ \\
\hline \multirow{2}{*}{$\begin{array}{c}\text { Overall } \\
\text { mean }\end{array}$} & Comfort & $\begin{array}{c}4.36^{\mathrm{C}} \pm 0.15 \\
\text { (36) }\end{array}$ & $\begin{array}{c}4.42^{\mathrm{C}} \pm 0.12 \\
\text { (36) }\end{array}$ & $\begin{array}{c}4.42^{\mathrm{C}} \pm 0.12 \\
\text { (36) }\end{array}$ & $\begin{array}{c}5.27^{\mathrm{B}} \pm 0.18 \\
(36)\end{array}$ \\
\hline & Heat & $\begin{array}{c}5.47^{\mathrm{b}} \pm 0.14 \\
(36)\end{array}$ & $\begin{array}{c}4.79^{b} \pm 0.14 \\
(36)\end{array}$ & $\begin{array}{c}4.79^{\mathrm{b}} \pm 0.14 \\
(36)\end{array}$ & $\begin{array}{c}5.51^{\mathrm{b}} \pm 0.17 \\
(36)\end{array}$ \\
\hline
\end{tabular}

Means bearing different superscripts within same row differ significantly $\left({ }^{\mathrm{ABC}} ; \mathrm{p}<0.01,{ }^{\mathrm{ab}} ; \mathrm{p}<0.05\right)$. Comfort $\left(26 \pm 1^{\circ} \mathrm{C}\right)$, Heat $\left(37 \pm 5^{\circ} \mathrm{C}\right)$

G1 (Control), G2 (100 mg vitamin E), G3 (200 mg vitamin E), G4 (300 mg vitamin E),

Table.3 Mean plasma glucose concentration ( $\mathrm{mg} / \mathrm{dl}$ ) of broilers at different intervals

\begin{tabular}{|c|c|c|c|c|c|}
\hline Period & Condition & G1 & G2 & G3 & G4 \\
\hline \multirow{2}{*}{$15^{\text {th }}$ day } & Comfort & $\begin{array}{l}266.5^{\mathrm{B}} \pm 11.6 \\
(12)\end{array}$ & $\begin{array}{c}286.7^{\mathrm{AB}} \\
\pm 11.9(12)\end{array}$ & $\begin{array}{c}302.08^{\mathrm{AB}} \\
\pm 8.99(12)\end{array}$ & $\begin{array}{c}314.13^{\mathrm{A}} \pm 6.57 \\
\text { (12) }\end{array}$ \\
\hline & Heat & $\begin{array}{c}243.1^{\mathrm{B}} \pm 10.8 \\
\quad(12)\end{array}$ & $\begin{array}{c}270.00^{\mathrm{AB}} \\
\pm 7.22(12) \\
\end{array}$ & $\begin{array}{c}283.3^{\mathrm{A}} \pm 19.4 \\
(12)\end{array}$ & $\begin{array}{c}309.25^{\mathrm{A}} \pm 5.75 \\
(12)\end{array}$ \\
\hline \multirow{2}{*}{$30^{\text {th }}$ day } & Comfort & $\begin{array}{c}252.51^{\mathrm{B}} \pm 7.78 \\
(12)\end{array}$ & $\begin{array}{c}281.8^{\mathrm{AB}} \pm 15.7 \\
(12)\end{array}$ & $\begin{array}{c}292.00 \\
\mathrm{AB}_{ \pm}+10.6(12)\end{array}$ & $\begin{array}{c}310.50^{\mathrm{A}} \pm 12.4 \\
\text { (12) }\end{array}$ \\
\hline & Heat & $\begin{array}{c}223.50^{\mathrm{C}} \pm 7.74 \\
(12)\end{array}$ & $\begin{array}{c}270.9^{\mathrm{B}} \pm 12.9 \\
(12)\end{array}$ & $\begin{array}{c}291.50^{\mathrm{AB}} \pm 18 \\
4(12)\end{array}$ & $\begin{array}{c}310.53^{\mathrm{A}} \pm 4.87 \\
(12)\end{array}$ \\
\hline \multirow{2}{*}{$45^{\text {st day }}$} & Comfort & $\begin{array}{c}238.83^{\mathrm{B}} \pm 7.55 \\
\quad(12)\end{array}$ & $\begin{array}{c}273.00^{\mathrm{A}} \pm 8.79 \\
\text { (12) }\end{array}$ & $\begin{array}{c}306.45^{\mathrm{A}} \pm 9.33 \\
\text { (12) }\end{array}$ & $\begin{array}{c}306.97^{\mathrm{A}} \pm 4.07 \\
\text { (12) }\end{array}$ \\
\hline & Heat & $\begin{array}{c}182.02^{\mathrm{B}} \pm 9.33 \\
(12)\end{array}$ & $\begin{array}{l}269.97^{\mathrm{A}} \pm \\
7.38(12)\end{array}$ & $\begin{array}{l}286.08^{\mathrm{A}} \pm 9.81 \\
\text { (12) }\end{array}$ & $\begin{array}{c}302.50^{\mathrm{A}} \pm 3.77 \\
\text { (12) }\end{array}$ \\
\hline \multirow{2}{*}{$\begin{array}{c}\text { Overall } \\
\text { mean }\end{array}$} & Comfort & $\begin{array}{c}252.61^{\mathrm{B}} \pm 5.48 \\
(36)\end{array}$ & $\begin{array}{c}280.50^{\mathrm{AB}} \pm 7.0 \\
6(36)\end{array}$ & $\begin{array}{c}300.18^{\mathrm{A}} \pm 5.51 \\
(36)\end{array}$ & $\begin{array}{c}310.37^{\mathrm{A}} \pm 4.76 \\
\quad(36)\end{array}$ \\
\hline & Heat & $\begin{array}{c}216.19^{\mathrm{C}} \pm 6.79 \\
(36)\end{array}$ & $\begin{array}{l}270.30^{\mathrm{B}} \pm \\
5.35(36)\end{array}$ & $\begin{array}{c}286.97^{\mathrm{AB}} \pm 9.2 \\
4(36)\end{array}$ & $\begin{array}{c}307.43^{\mathrm{A}} \pm 2.79 \\
\quad(36)\end{array}$ \\
\hline
\end{tabular}

Means bearing different superscripts within same row differ significantly $\left({ }^{\mathrm{ABC}} ; \mathrm{p}<0.01\right)$.

Comfort $\left(26 \pm 1^{\circ} \mathrm{C}\right)$, Heat $\left(37 \pm 5^{\circ} \mathrm{C}\right)$

G1 (Control), G2 (100 mg vitamin E), G3 (200 mg vitamin E), G4 (300 mg vitamin E) 
Table.4 Mean plasma albumin concentration (g/dl) of broilers at different intervals

\begin{tabular}{|c|c|c|c|c|c|}
\hline Period & Condition & G1 & G2 & G3 & G4 \\
\hline \multirow{2}{*}{$15^{\text {th }}$ day } & Comfort & $\begin{array}{c}1.65^{\mathrm{B}} \pm 0.08 \\
(12)\end{array}$ & $\begin{array}{c}2.40^{\mathrm{AB}} \pm 0.10 \\
(12)\end{array}$ & $\begin{array}{c}3.16^{\mathrm{A}} \pm 0.20 \\
(12)\end{array}$ & $\begin{array}{c}3.49^{\mathrm{A}} \pm 0.14 \\
(12)\end{array}$ \\
\hline & Heat & $\begin{array}{c}1.33^{\mathrm{b}} \pm 0.87 \\
(12)\end{array}$ & $\begin{array}{c}1.80^{\mathrm{ab}} \pm 0.12 \\
(12)\end{array}$ & $\begin{array}{c}3.12^{\mathrm{ab}} \pm 0.14 \\
(12)\end{array}$ & $\begin{array}{c}3.37^{\mathrm{a}} \pm 0.16 \\
(12)\end{array}$ \\
\hline \multirow{2}{*}{$30^{\text {th }}$ day } & Comfort & $\begin{array}{c}1.76^{\mathrm{b}} \pm 0.14 \\
\text { (12) }\end{array}$ & $\begin{array}{c}2.90^{\mathrm{ab}} \pm 0.22 \\
(12)\end{array}$ & $\begin{array}{c}3.80^{\mathrm{A}} \pm 0.18 \\
(12)\end{array}$ & $\begin{array}{c}4.17^{\mathrm{A}} \pm 0.1 .4 \\
(12)\end{array}$ \\
\hline & Heat & $\begin{array}{c}1.60^{\mathrm{B}} \pm 0.06 \\
(12)\end{array}$ & $\begin{array}{c}2.54^{\mathrm{AB}} \pm 0.15 \\
(12)\end{array}$ & $\begin{array}{c}3.48^{\mathrm{A}} \pm 0.13 \\
\text { (12) }\end{array}$ & $\begin{array}{c}4.00^{\mathrm{A}} \pm 0.19 \\
(12)\end{array}$ \\
\hline \multirow{2}{*}{$45^{\text {st }}$ day } & Comfort & $\begin{array}{c}1.83^{\mathrm{b}} \pm 0.12 \\
(12)\end{array}$ & $\begin{array}{c}3.53^{\mathrm{ab}} \pm 0.14 \\
(12)\end{array}$ & $\begin{array}{c}4.43^{\mathrm{ab}} \pm 0.11 \\
(12)\end{array}$ & $\begin{array}{c}4.90^{\mathrm{a}} \pm 0.18 \\
(12)\end{array}$ \\
\hline & Heat & $\begin{array}{c}1.60^{C} \pm 0.09 \\
(12)\end{array}$ & $\begin{array}{c}2.64^{\mathrm{BC}} \pm 0.15 \\
(12)\end{array}$ & $\begin{array}{c}3.76^{\mathrm{AB}} \pm 0.66 \\
(12)\end{array}$ & $\begin{array}{c}4.70^{\mathrm{A}} \pm .0 .15 \\
(12)\end{array}$ \\
\hline \multirow{2}{*}{$\begin{array}{c}\text { Overall } \\
\text { mean }\end{array}$} & Comfort & $\begin{array}{c}1.74^{\mathrm{B}} \pm 0.07 \\
(36)\end{array}$ & $\begin{array}{c}2.94^{\mathrm{AB}} \pm 0.12 \\
(36)\end{array}$ & $\begin{array}{c}3.97^{\mathrm{A}} \pm 0.13 \\
(36)\end{array}$ & $\begin{array}{c}4.19^{\mathrm{A}} \pm 0.13 \\
(36)\end{array}$ \\
\hline & Heat & $\begin{array}{c}1.51^{\mathrm{C}} \pm 0.05 \\
(36)\end{array}$ & $\begin{array}{c}2.33^{\mathrm{BC}} \pm 0.10 \\
(36)\end{array}$ & $\begin{array}{c}3.45^{\mathrm{B}} \pm 0.09 \\
(36)\end{array}$ & $\begin{array}{c}4.02^{\mathrm{A}} \pm 0.13 \\
(36)\end{array}$ \\
\hline
\end{tabular}

Means bearing different superscripts within same row differ significantly $\left({ }^{\mathrm{ABC}} ; \mathrm{p}<0.01,{ }^{\mathrm{abc}} ; \mathrm{p}<0.05\right)$.

Comfort $\left(26 \pm 1^{\circ} \mathrm{C}\right)$, Heat $\left(37 \pm 5^{\circ} \mathrm{C}\right), \mathrm{G} 1$ (Control), G2 (100 mg vitamin E), G3 (200 mg vitamin E),

G4 (300 mg vitamin E)

Table.5 Breast muscle $\mathrm{pH}$ and thiobarbituric acid value in liver homogenates of broilers

\begin{tabular}{|l|l|c|c|c|c|}
\hline Birds & Condition & G1 & G2 & G3 & G4 \\
\hline \multirow{2}{*}{ Breast Muscle pH } & Comfort & 6.8 & 6.6 & 6.7 & 6.5 \\
\cline { 2 - 6 } & Heat & 6.6 & 6.5 & 6.6 & 6.3 \\
\hline \multirow{2}{*}{$\begin{array}{l}\text { TBA (nmol MDA } \\
\text { equivalent/mg wet tissue) }\end{array}$} & Comfort & 5.01 & 2.93 & 3.46 & 2.88 \\
\cline { 2 - 6 } & Heat & 5.74 & 3.48 & 2.44 & 2.20 \\
\hline
\end{tabular}

Comfort $\left(26 \pm 1^{\circ} \mathrm{C}\right)$, Heat $\left(37 \pm 5^{\circ} \mathrm{C}\right)$

G1 (Control), G2 (100 mg vitamin E), G3 (200 mg vitamin E), G4 (300 mg vitamin E)

However, non-significant difference was observed between G1 and G2. Similar trend was also observed between G3 and G4 groups. The overall mean concentration of albumin showed non-significant difference between comfort and heat stressed birds in all the groups supplemented with vitamin E. In both heat stressed and comfort condition, a significant difference was observed in 200 and $300 \mathrm{mg}$ vitamin E supplemented group of broilers as compared to that of control. In the present findings, the vitamin E supplemented birds had higher serum albumin level as compared to control group of broilers. Sahin et al., (2002) found that albumin concentrations increased linearly with dietary vitamin $\mathrm{E}$ supplementations which were in agreement to present findings. Also Ismail et al., (2014) reported that the was significant increase in the plasma albumin concentrations with dietary $300 \mathrm{mg} \mathrm{kg}^{-1}$ vitamin $\mathrm{E}$ supplementation, which were in agreement with the present findings.

The increase of serum albumin concentrations observed in experimental groups of present 
investigation could be partially explained by the fact that this increase might because of the reduction of synthesis (lipids and protein through non-carbohydrate source) and secretion of corticoids in birds supplemented with vitamin $\mathrm{E}$. The probable reason for such increase in concentrations of albumin might be due to the fact that, at temperatures above thermoneutral zone, corticoid secretion increases as a response to stress.

The data recorded and analyzed for breast muscle $\mathrm{pH}$ and TBA value is presented in table 5. On day 45, in the comfort condition, the higher breast muscle $\mathrm{pH}$ of 6.8 and 6.7 was observed in control and G2 group of sacrificed broilers, whereas, the lower $\mathrm{pH}$ of 6.5 was recorded in G4, supplemented with $300 \mathrm{mg}$ alpha-tocopherol. On day 45, in heat stressed condition, the higher breast muscle $\mathrm{pH}$ of 6.6 was observed in control group of sacrificed broilers, whereas, the lower $\mathrm{pH}$ of 6.3 was recorded in G4, supplemented with $300 \mathrm{mg}$ alpha-tocopherol. On day 45, in both comfort and heat stressed condition, supplementation with $300 \mathrm{mg}$ vitamin $\mathrm{E}$ recorded numerically lower breast muscle $\mathrm{pH}$ as compared to control sacrificed broilers. The $\mathrm{pH}$ of the sacrificed birds is comparatively higher as compared to the ultimate $\mathrm{pH}$ obtained after few hours of sacrifice, which suggests the beneficial effect of vitamin $\mathrm{E}$ supplementation in broilers. Zaferino et al., (2015) found that beast muscle $\mathrm{pH}$ decrease numerically with dietary vitamin E supplementation and these findings are in agreement to present findings. The possible justification for present findings might be the fact that high ambient temperatures reduce the bird's feed intake and impose physiological stresses, which activate glycogenolysis in skeletal muscle (Kreikemeier et al., 1998). Physiologically stressed birds use glucose and gluconeogenic precursors as their major oxidative fuel. Low muscle glycogen content resulting from exhaustion or chronic stress before death results in high $\mathrm{pH}$ values and minimal rigor shortening, which could be one of the significant factors causing deterioration of meat quality characteristics.

In the comfort condition, the higher TBA value of sacrificed broilers on day 45 was $5.01 \mathrm{nmol}$ MDA equivalent / $\mathrm{mg}$ wet tissue in control group whereas, the lower TBA value was recorded $2.88 \mathrm{nmol}$ MDA equivalent / mg wet tissue in G4, which was supplemented with $300 \mathrm{mg}$ alpha-tocopherol. In the heat stressed condition, the higher TBA value of sacrificed broilers on day 45 was $5.74 \mathrm{nmol}$ MDA equivalent / $\mathrm{mg}$ wet tissue in control group whereas, the lower TBA value was recorded $2.20 \mathrm{nmol}$ MDA equivalent / $\mathrm{mg}$ wet tissue in G4, which was supplemented with $300 \mathrm{mg}$ alpha-tocopherol.

The thiobarbituric acid value (nmol MDA equivalent / $\mathrm{mg}$ wet tissue) of sacrificed broilers was numerically lower in $300 \mathrm{mg}$ vitamin E supplemented birds as compared control birds during comfort and heat stresses conditions. Ismail et al., (2014) reported that supplementation of vitamin $\mathrm{E}$ in feed has decreasing effect of MDA. These findings were in agreement to present findings.

High environmental temperature is a major stress factor for poultry and induces adverse effects on performance as well as on anatomical, physiological and behavioural parameters and may lead to exhaustion or even death. Hence, there is a need to explore the efficient means to improve the thermo tolerance of broiler chickens in hot climates without affecting their productivity. Hence nutritional manipulation with inclusion of anti-stress compounds like vitamins, make a practical alternative in alleviating the effects of high ambient temperature in poultry. The present results found that supplementation of the diets with antioxidants like vitamin $\mathrm{E}$, is essential to overcome the deleterious effects 
of heat stress conditions on the oxidative status and performance of broilers.

\section{Acknowledgements}

The authors would like to acknowledge, M.P. Biotechnology Council, Bhopal (M.P) for providing financial assistance for the research project.

\section{References}

Doumas, B.T., Arends, R.L. and Pinto, P.C. 1972. Standard Methods of Clinical Chemistry, $7^{\text {th }}$ Edn, Academic Press, Chicago, pp 175-189.

Ismail, F.S.A., El-Gogary, M.R. and El-Nadi, M.I. 2014. Influence of Vitamin E Supplementation and Stocking Density on Performance, Thyroid Status, Some Blood Parameters, Immunity and Antioxidant Status in Broiler Chickens. Asian Journal of Animal and Veterinary Advances, 9(11): 702-712.

Khatibjoo, A., Ranjbar, K., Neamati, M. and Fattahnia, F. 2014. Effects of vitamin C, Echium amoenum and lavender extract on blood metabolite and meat quality of broiler chickens under transport stress. Global Journal of Animal Scientific Research, 2: 159-169.

Kreikemeier, K.K., Unruh, J.A. and Eck, T.P. 1998. Factors affecting the occurrence of dark-cutting beef and selected carcass traits in finished beef cattle. Journal of Animal Science, 76: 388-395.

Navid, H.M., Saeid, C.A., Asghar, A., Tehrani, A.L. and Mostaan, K.M. 2010. Influence of dietary vitamin $\mathrm{E}$ and zinc on performance, oxidative stability and some blood measures of broiler chickens reared under heat stress $\left(35^{\circ} \mathrm{C}\right)$. Journal of Agrobiology, 27(2): 103-110.

Niu, Z.Y., Liu, F.Z., Yan, Q.L. and Li, W.C. 2009. Effect of different levels of vitamin $\mathrm{E}$ on growth performance and immune responses of broiler under heat stress. Poultry Science, 88: 2101-2107.

NRC, 1994. Nutrient Requirement of Poultry $9^{\text {th }}$ Rev Edn., National Research Council, National Academy Press, Washington, DC, 20418.

Omaye, S.T., Turnbull, J.D. and Sauberlich, H.E. 1979. Selected methods for the determination of ascorbic acid in animal cells, tissues and fluids. Methods in Enzymology, 62: 1-7.

Petracci, M., Betti, M. and Cavani, C. 2004. Color variation and characterization of broiler breast meat during processing in Italy. Poultry Science, 83: 2085-2092.

Pileggi, V.J., and Szuskeiweiz, 1974. Carbohydrates. In: Henry Richard J., C. Canon Donald and W. Winkelman James (eds.) Clinical Chemistry. Principles and Techniques. $2^{\text {nd }}$ Edn, Harper and Row Publishers, New York. pp 1265-1325.

Sahin, K., Kucuk, O., Sahin, N. and Gursu, M.F. 2002. Optimal dietary concentration of vitamin $\mathrm{E}$ for alleviating the effect of heat stress on performance, thyroid status, ACTH and some serum metabolite and mineral concentrations in broilers. Veterinary Medicine, 47: 110-116

Sahın, K.N., Sahın, M., Ondercı, S., Yaralıoglu and Kucuk, O. 2001. Protective role of supplemental vitamin $\mathrm{E}$ on lipid peroxidation, vitamins $\mathrm{E}, \mathrm{A}$ and some mineral concentrations of broilers reared under heat stress. Veterinary Medicine, 46: 140-144.

Sahin, N., Sahin, K. and Küçük, O. 2001. Effects of vitamin $\mathrm{E}$ and vitamin $\mathrm{A}$ supplementation on performance, thyroid status and serum concentrations of some metabolites and minerals in broilers reared under heat stress $\left(32^{\circ} \mathrm{C}\right)$. Veterinary Medicine, 46 (11-12): 286292. 
Siegel, H.S., 1995. Stress, strains and resistance. British Poultry Science, 36: 03-22.

Snedecor G.W., and Cochran, W.G. 1994. Statistical Method $8^{\text {th }}$ Edn, The lowa State University Press, Ames, lowa, USA.

Sturkie, P.D., 1986. Avian Physiology 4th Edn, Springer-Verlag International Co.,
New York, USA, pp 221-252.

Zeferino, C.P., Komiyama, C.M., Pelícia, V.C., Fascina, V.B., Aoyagi, M. M., Coutinho, L.L., Sartori, J.R., and Moura, A.S.A.M.T. 2016. Carcass and meat quality traits of chickens fed diets concurrently supplemented with vitamins $\mathrm{C}$ and $\mathrm{E}$ under constant heat stress. Animal, 10(1):163-171.

\section{How to cite this article:}

Amir Amin Sheikh, Aditya Mishra, Kailash Kumar, Pragati Patel, A.K. Jain, Showkeen M. Bashir and Aarif Ali. 2017. Effect of Alpha-Tocopherol on Biochemical Parameters in Commercial Broilers during Heat Stress. Int.J.Curr.Microbiol.App.Sci. 6(10): 531-539. doi: https://doi.org/10.20546/ijcmas.2017.610.065 